\title{
Formation of mechanism of programme management for the development of medical organizations
}

\author{
Angela Mottaeva ${ }^{1, *}$ \\ Moscow State University of Civil Engineering, 129337, 26, Yaroslavskoye Shosse, Moscow, Russia
}

\begin{abstract}
The author recognizes that the search of new approaches to management is necessary for providing the Municipal Healthcare System with sustainable development of medical institutions. The author finds out the factors of the internal and external environment, restrictions and conditions, influencing the processes of formation of mechanisms of programme management for the development of the organizations of the medical sphere. The activity of the leading Russian organizations of the medical sphere was analysed. It was proved, that these organizations has low medical and economic efficiency, when forming their mechanisms of programme management for the development of the organizations of the medical sphere. The author has developed some recommendations for the improvement of processes of formation of mechanisms of programme management, in order to provide the organizations of the medical sphere and the Municipal Healthcare System as whole with sustainable development. At the same time, the importance of such development for social stability and comfort of cities is emphasized.
\end{abstract}

\section{Introduction}

Under modern market conditions, there is the need of increase in the efficiency of processes of formation of mechanisms of programme management for the development of the medical organizations. The programme management for the development of the organizations of the medical sphere which are constantly developing and adapted to changes of the internal and external environment demands selection and use of new managerial approaches, methods, principles and tools. That is the reason of the need of development and improvement of mechanisms of programme management for the development of the organizations of the medical sphere taking into account economic, organizational, managerial and other factors.

One can point out such authors, developing the matters of project and programme management R.T. Fatrell, Donald F. Shafer, Linda I. Shafer, Russell D. Archibald, etc.

Nevertheless, methodological and practical problems of formation of mechanisms of programme management for the development in the organizations of the medical sphere are not fully studied. Therefore, the matters of formation and effective introduction of

\footnotetext{
*Corresponding author: angela-1309.m@yandex.ru
} 
mechanisms of programme management for the development of the organizations of the medical sphere demand additional development and carrying out some research in the field. That has induced the author to conduct the research, which has become the base of this article.

\section{Terms and Methods}

For the research of the problem of formation of mechanisms of programme management for the development of the organizations of the medical sphere it is necessary to give the definition to the terms "organization of the medical sphere", "project" and "investment programme". The organization of the medical sphere is the organization, which is carrying out its activity in the field of healthcare or rendering medical services, keeping development of medicine as sciences, engaged in actions for the maintenance of health and delivery of healthcare to people by the means of studying, diagnostics, treatment and possible prevention of diseases and injuries [1,2].

For the operating organizations and organizations under construction, it is vitally important to form their mechanisms of management of programmes of development, to develop innovative processes for the development and the release of new medical services as well as for involvement of domestic and foreign investors.

There are different definitions of the concept "investment programme". For example, the programme can be submitted as the set of the projects, united by a common goal, allocated resources, time for its performance, technology, organization, etc.

In some applied fields, project management and programme management are considered to be synonyms. In some other fields, project management is the subset of programme management or on the contrary [1-5]. The author of the article uses the concept of the programme of development as the set of investment-and-innovative projects with the set purpose, while the projects are meant to be the purposeful actions with restrictions on dates of performance, the budget and quality of services.

According to the author, there are certain differences between the programme management and the project management, caused by the different nature of these subjects (Table 1).

Table 1. Comparative analysis of programme management and project management for the development of the organizations of the medical sphere.

\begin{tabular}{|c|c|}
\hline Programme & Project \\
\hline Many projects, realized at the same time. & $\begin{array}{c}\text { One project, realized during a certain period of } \\
\text { time }\end{array}$ \\
\hline Dominant of the whole programme purposes. & Dominant of the project purposes. \\
\hline $\begin{array}{c}\text { Taking into account the interrelations of the } \\
\text { projects. }\end{array}$ & $\begin{array}{c}\text { Interrelations of projects are not the subject of } \\
\text { special consideration. }\end{array}$ \\
\hline $\begin{array}{c}\text { The integrated plans (at the level of the } \\
\text { programme). }\end{array}$ & Detailed plans \\
\hline $\begin{array}{c}\text { Aspiration to maximizing of the efficiency of } \\
\text { the resources use. }\end{array}$ & $\begin{array}{c}\text { Aspiration to demand for resources } \\
\text { minimization. }\end{array}$ \\
\hline \begin{tabular}{c} 
Great uncertainty in the implementation terms. \\
\hline Fundamental difference of projects tasks. \\
Aspiration to inter-project distribution of \\
resources.
\end{tabular} & More certain terms of implementation. \\
\hline
\end{tabular}

These distinctions need to be considered within the investment programme management in the medical sphere. 


\section{Results}

As the result of the research conducted, the author revealed some factors of the internal and external environment, some restrictions and conditions, influencing the processes of formation of mechanism of programme management for the development of the organizations of the medical sphere.

The scheme of the external and internal factors, influencing on formation of the mechanism of the programme management for the development, is presented in Figure 1.

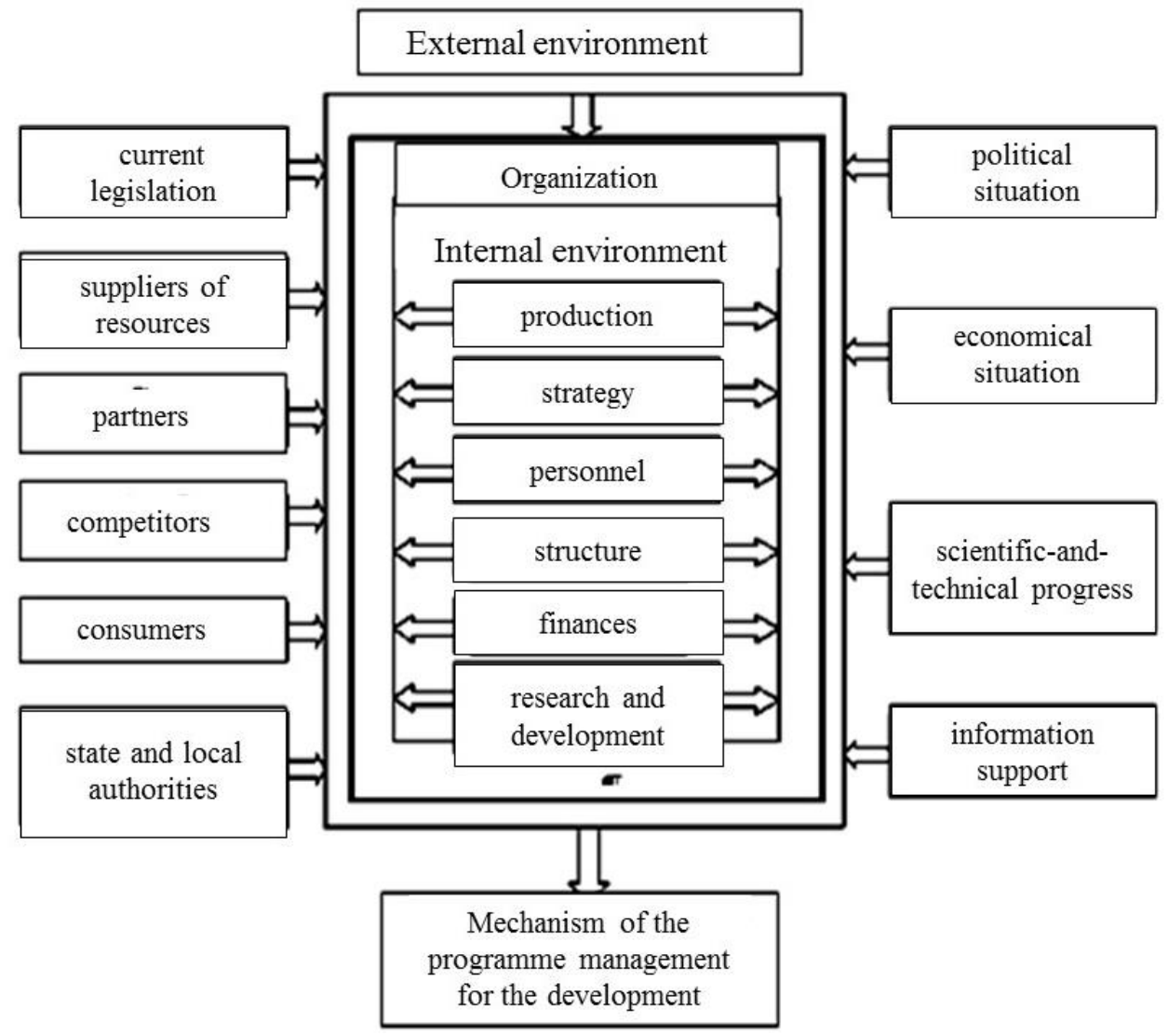

Fig. 1. The factors of external and internal environment, influencing the formation of the mechanism of programme management for the development of the organizations of the medical sphere.

The ability of the organizations of the medical sphere to overcome crises, to win competition, to keep economic stability in many respects depends on the action of internal factors (that is from the condition of its internal environment). Before the organizations of the medical sphere have been considered as a closed production system, and the influence of the environment on their development was practically not studied. That was considered, that the external environment does not practically affect the organization, and scientific research have been generally directed to the studying and improvement of the internal environment. However, in the conditions of market economy the organization of the medical sphere cannot ignore the influence of the external environment, since it means bankruptcy of the organization in the nearest future.

The development programme is also formed according to some restrictions, which can arise both in the organization and outside. In this case legislative rules, inflation, 
competitors, changes in the economy as whole, financial performance, etc. can act as the external restrictions. The principles of the organization, level of expenses, production capacities, and the condition of marketing and managerial potential can serve as internal restrictions.

Besides, the processes of formation of the mechanism of programme management for the development of the organizations of the medical sphere take place in certain conditions. That is possible to allocate the following conditions, when forming the mechanism of programme management for the development of the organization of the medical sphere:

1) preference needs to be given to the competitive positions for the long-term outlook;

2) processes of formation have to be provided with all the necessary means and first of all with financial resources;

3) managers of all levels have to understand the mechanisms of management in the form of the system of accurate strategic and operating plans of development and carry out the formation strictly according to the operating plan of realization of strategic changes;

4) managers have to comprehend, that carefully thought over strategy creates the organizations of the medical sphere strong competitive positions and positive business reputation;

5) that is possible to enter the competition, only when there is "margin of safety".

The author of this article has carried out the analysis of formation of the mechanism of programme management for the development of the leading organizations of the medical sphere. As the result of the analysis of the organizations of the medical sphere, it has been revealed that all these organizations not effectively exercise formation of control mechanism for the programmes of development of the organizations of the medical sphere. That is possible to name the reasons determining this situation: imperfection or lack of effective tools of programme management; lack of the concept and the complex of mechanism of the programme management for the development of the organizations of the medical sphere; absence of experts in the field of programme management; difficulties in providing with the necessary investment means; insufficiency of experience of the management, etc.

As the result of the analysis of the problems of formation of the mechanism of programme management for the development in the organizations of the medical sphere, the author has developed offers and recommendations on the improvement of processes of formation of the mechanism of programme management for the development of the organizations of the medical sphere (Table 2).

Table 2. Offers and recommendation on the improvement of processes of the formation of the mechanism of programme management for the development of some organizations of the medical sphere

\begin{tabular}{|l|l|l|}
\hline $\begin{array}{c}\text { Name of } \\
\text { organization }\end{array}$ & \multicolumn{1}{|c|}{$\begin{array}{c}\text { Realized mechanism of the } \\
\text { programme management for the } \\
\text { development }\end{array}$} & Offers and recommendation \\
\hline $\begin{array}{l}\text { "Scientific } \\
\text { Nentre }\end{array}$ of & $\begin{array}{l}\text { Stage-by-stage implementation of the } \\
\text { mechanism of management in the } \\
\text { Metabolic Health programme for the } \\
\text { development and employment of the } \\
\text { complex of the personified diagnostics } \\
\text { of metabolic violations (2016 -2018) }\end{array}$ & $\begin{array}{l}\text { Development and implementation } \\
\text { of the instructions, regulating } \\
\text { stages of realization of } \\
\text { mechanisms of management of } \\
\text { the programme of development } \\
\text { and implementation of a complex } \\
\text { of personified diagnostics of } \\
\text { metabolic violations. }\end{array}$ \\
\hline $\begin{array}{l}\text { "Integrated } \\
\text { hospital and } \\
\text { policlinic" }\end{array}$ & $\begin{array}{l}\text { Mechanisms of management of the } \\
\text { programme for creation of the system } \\
\text { of hyperbaric oxygenation (according }\end{array}$ & $\begin{array}{l}\text { It is recommended to reconsider } \\
\text { the mechanisms of programme } \\
\text { management for creation of }\end{array}$ \\
\hline
\end{tabular}




\begin{tabular}{|c|c|c|}
\hline & $\begin{array}{l}\text { to the plan of the development and } \\
\text { implementation of the system until } \\
\text { 2019). Mechanisms of management of } \\
\text { the programme for creation of the } \\
\text { system of hyperbaric oxygenation } \\
\text { (according to the plan of the } \\
\text { development and implementation of } \\
\text { the system until 2019). }\end{array}$ & $\begin{array}{l}\text { system of hyperbaric oxygenation } \\
\text { in respect of the efficiency, as } \\
\text { well as to revise the scheme of } \\
\text { implementation of the projects, } \\
\text { entering the development } \\
\text { programme. }\end{array}$ \\
\hline $\begin{array}{l}\text { "Federal } \\
\text { Medical-and- } \\
\text { Biological } \\
\text { Agency" }\end{array}$ & $\begin{array}{l}\text { Mechanisms of management of the } \\
\text { innovative programme the for } \\
\text { development and putting into operation } \\
\text { of the installation for hypoxytherapy } \\
(2017-2019)\end{array}$ & $\begin{array}{l}\text { It is recommended: } \\
\text {-to systematize the mechanisms } \\
\text { of project management, entering } \\
\text { the innovative programme for } \\
\text { development and putting into } \\
\text { operation of the installation for } \\
\text { hypoxytherapy (2017-2019), for } \\
\text { increase in efficiency; } \\
\text { - to optimize the mechanisms of } \\
\text { management of the separate } \\
\text { projects entering the programme } \\
\text { that will lead to reduction on time } \\
\text { of a cycle of implementation of } \\
\text { the program and loss of working } \\
\text { hours, } \\
\text {-to create and balance the uniform } \\
\text { system of mechanisms of } \\
\text { management of the innovative } \\
\text { programme. }\end{array}$ \\
\hline "INPROMED" & $\begin{array}{l}\text { Mechanisms of management of the } \\
\text { programme for the development and } \\
\text { introduction into operation of the } \\
\text { magnetic and resonant tomograph } \\
(2017-2018)\end{array}$ & $\begin{array}{l}\text { For reduction of term of } \\
\text { implementation of the } \\
\text { mechanisms of programme } \\
\text { management and increase in } \\
\text { efficiency, it is necessary to unite } \\
\text { separate all-target projects in the } \\
\text { general programme. }\end{array}$ \\
\hline $\begin{array}{l}\text { "Careful } \\
\text { doctor" }\end{array}$ & $\begin{array}{l}\text { Mechanisms of management of the } \\
\text { programme for the development and } \\
\text { introduction into operation of new } \\
\text { biochemical analysers }(2016-2019)\end{array}$ & $\begin{array}{l}\text { To balance the mechanisms of } \\
\text { project management, entering the } \\
\text { programme for development and } \\
\text { introduction of new biochemical } \\
\text { analysers, among themselves. }\end{array}$ \\
\hline
\end{tabular}

Having passed from particular recommendations to the general technique, the author offers the following algorithm of formation of mechanisms of programme management for the medical organisations development (Fig. 2). 


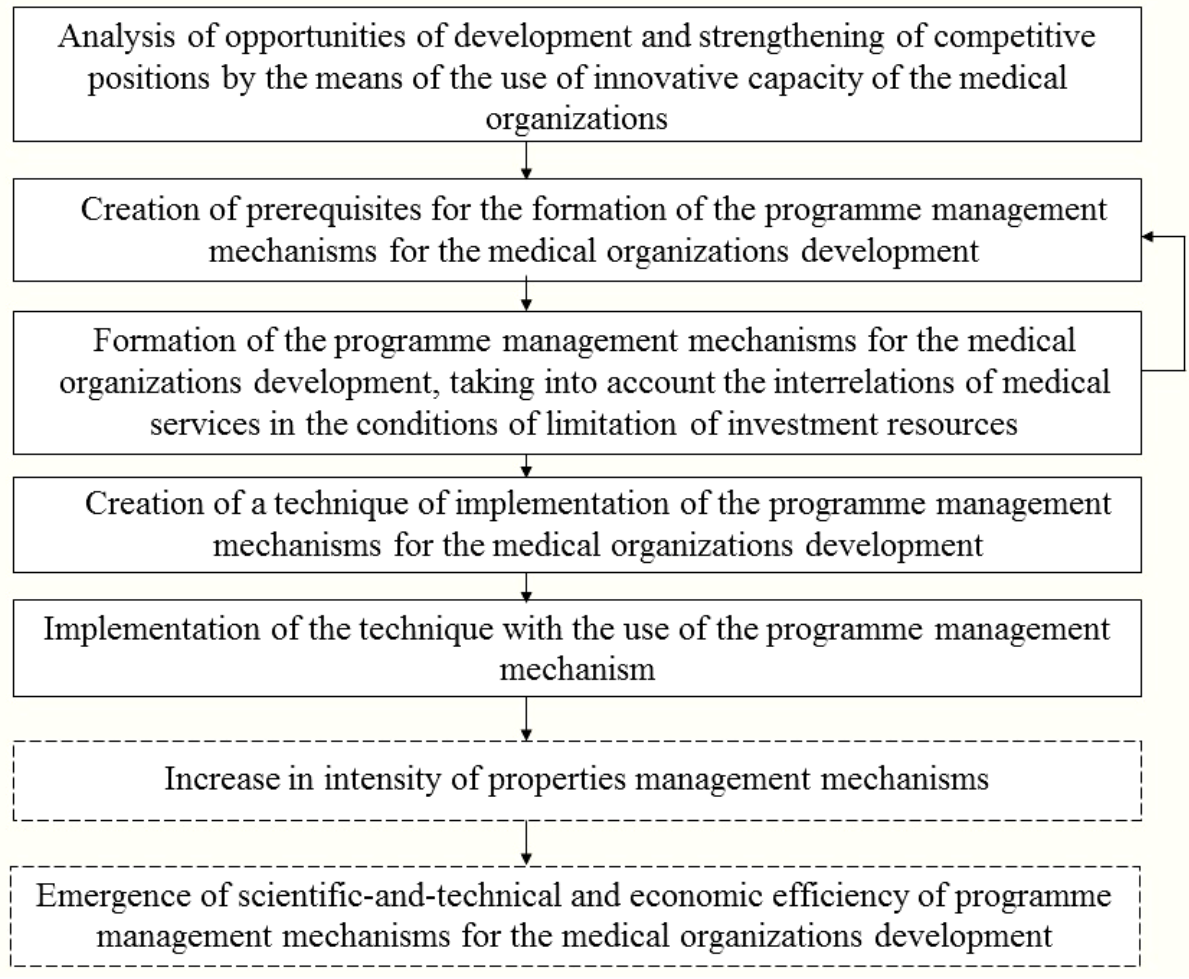

Fig. 2. Integrated algorithm of formation the programme management mechanisms for the medical organizations development

The proposed measures have to be certainly used in a complex.

\section{Discussion}

Various methods of formation of the mechanism of programme management for the development of the organizations of the medical sphere have their advocates $[11,12]$.

1. Economic methods are based on the social-and-economic laws and regularities of the development of the objective world (the nature, society and thinking itself). The use of these methods is based on the system of economic interests of the individual, collective and society.

2. Organizational-and-managerial methods are based on some direct orders.

3. Social-and-psychological (sometimes they are called educational) methods of formation of the mechanism of programme management are based on the formation and development of public opinion, about some moral values, which are socially and individually significant: good and evil, the essence of life, moral principles in society, attitudes towards the individual, etc.

Most of the authors put economic methods into the central place. That is caused by the fact that the relations of management are defined, first of all, by the economic relations and objective needs and the interests of people, which are their cornerstone $[13,14,15,16]$.

According to the author of this article, the economic methods would be effective, if it was necessary to provide first of all the "responsiveness" of the organization on economic levers. Otherwise, the expansion of the rights of structural units and self-financing of the organization lose their meaning. In turn, the expansion of independence leads to the greater 
freedom of collectives within the economic activity and to economic methods of the management. Only in the conditions of reasonable independence real transition to economic methods of the management is possible: when the collective disposes of supply available, the gained income (profit), salary.

\section{Conclusion}

Formation and implementation of the mechanism of programme management for the development of the organizations of the medical sphere is connected with the necessity of reorganization of the organization or its restructuring along with the current productions. The study of separate elements of the programme management for the development, introduction of new technologies into the processes of management in the organizations of the medical sphere, development of the concept and the complex of the mechanism on programme management for the development of the organizations of the medical sphere, would allow to provide more effective improvement of programme management in the organizations of the medical sphere. These changes need to be combined with the life cycles of medical products, technologies and organization.

\section{References}

1. A.Trushkin, L. Demyanova, N. Malakhova, Economics and and management in the health care sphere (Phoenix, Moscow, 2015)

2. A guidebook of Projekt\&Program Management For Enterprise Innovation, (PMCC/ENNA, Japan, 2012)

3. E. Vasilyeva, I. Polyakova, MATEC Web of Conferences, 106, 08097 (2017)

4. N. Khan, Financial model of health care sphere (Delo, Moscow, 2013)

5. E. Akimova, G. Potasheva, MATEC Web of Conferences, 106, 08080 (2017)

6. E. Vasilyeva, A. Zlentenkov, O. Suzneva, E. Sapozhnikova, IOP (Earth and Environmental Science), 9012122 (2017)

7. D. Russel Managing of High-Technology Programs and Projects (John Wileg \& Sons Inc., New York, 2012)

8. Thomson S. et al, Financing health care in the European Union: challenges and policy responses (World Health Organization on behalf of the European Observatory on Health Systems and Policies, EU, 2009).

9. T. Meshcheriakova, IOP Conf. Series: Earth and Environmental Science, 90, 012118, (2017)

10. Paris V., Devaux M., Wei L., Health Systems Institutional Characteristics: A Survey of 29 OECD Countries (OECD Health Working Papers, No. 50, OECD Publishing, 2010)

11. T. Meshcheriakova, Applied and Fundamental Studies, 2, 186-188 (2017)

12. I. Polyakova, E. Chibisova, Economy and entrepreneurship, 5 (70) 579-582

13. I. Karakozova, Y. Prokhorova. Economy and Entrepreneurship, 2-1 (67-1), 609-612. (2016)

14. I. V. Ilin, A. Lepekhin, A.I. Levina, O Yu. Iliashenko, Advances in Intelligent Systems and Computing, 692, 1306-1314 (2018) DOi -10.1007/978-3-319-70987-1_138

15. I. V. Ilin, A.I. Levina, O Yu. Iliashenko, MATEC Web of Conferences, 106, 08066 (2017) DOi-10.1051/matecconf/201710608066 
16. V. V. Gluhov, I. V. Ilin, Lecture Notes in Computer Science, 8638, 509- 518 (2014) DOi-10.1007/978-3-319-10353-2_46 